\title{
Computer Phobia among Adult University Students
}

\author{
Kamariah Yunus (Corresponding author) \\ Centre of English Language Studies, Faculty of Languages and Communication, Universiti Sultan Zainal Abidin, Gong Badak Campus, Malaysia \\ E-mail: kamariah@unisza.edu.my \\ Wahidah Wahid \\ Centre of English Language Studies, Faculty of Languages and Communication, Universiti Sultan Zainal Abidin, Gong Badak Campus, Malaysia \\ SNM Syed Omar \\ Centre of English Language Studies, Faculty of Languages and Communication, Universiti Sultan Zainal Abidin, Gong Badak Campus, Malaysia \\ Radzuwan Ab Rashid \\ Centre of English Language Studies, Faculty of Languages and Communication, Universiti Sultan Zainal Abidin, Gong Badak Campus, Malaysia
}

Received: 22-05-2016

Published: 01-11-2016
Accepted: 27-08-2016

doi:10.7575/aiac.ijalel.v.5n.6p.209
Advance Access Published: September 2016

URL: http://dx.doi.org/10.7575/aiac.ijalel.v.5n.6p.209

\begin{abstract}
The use of Information and Communication Technology (ICT) in English Language Learning and Teaching (ELLT) has become prevalent in this recent decade. This study aims to investigate the level of computer technophobia among 106 adult undergraduates in a public university in Malaysia who utilised an e-Learning tool as the main medium of English learning. This descriptive study employed 65 Likert-scale items of Rosen and Weils' Measuring Technophobia Instrument (MTI), i.e. Computer Anxiety Rating Scale (CARS-S). Results showed that the respondents had a moderate level of computer anxiety, but female students had higher technophobic level compared to their male counterparts. This study concluded that computer anxiety is a feeling commonly experienced by many students studying English via eLearning tools. However, constant monitoring both from the instructors and ICT experts must be present in order to reduce technophobia among students. It is recommended to train and equip adult university students with sufficient computer skills prior to conducting any e-Learning programmes.
\end{abstract}

Keywords: ICT, independent learners, UniSZA e-learning tools (KeLiP), computer anxiety levels, technophobia

\section{Introduction}

The $21^{\text {st }}$ century has witnessed a revolution in education with the advancement of Information and Communication Technology (ICT). Modern and sophisticated electronic devices and e-Learning tools have been blended and integrated in the curriculum and syllabuses to make learning and teaching activities become more interesting, interactive, and fast. In many countries in the world, the use of technology in classroom is made compulsory as a means of improving education and the countries' success (Ness \& Chia-Ling, 2015; Bates, 2001), especially among adult learners in higher institutions comprising young adults (aged 19-35) and middle-aged adults (aged 36-54).

In line with the advancement of Information and Communication Technology (ICT) in this new millennium (Kern, 2006), it has become the aspiration of Malaysian Higher Education (MoHE) to promote independent learners, and to provide opportunities for adults in the job sectors to continue their studies in the e-Learning (electronic) mode. The utilization and integration of ICT tools in ELLT may enhance learners' opportunity to improve their English language competence and performance, thus elevating the quality of their learning experience. Because of this, a myriad of emerging e-Learning systems have been employed both at the public and private Malaysian tertiary institutions. These include, among others, ezylearn at Universiti Malaysia Kelantan (UMK), PutraLMS at Universiti Putra Malaysia (UPM), MyLMS at Open Universiti Malaysia (OUM), and KeLiP (KUSZA e-Learning Programme) at Sultan Zainal Abidin University (UniSZA). These e-Learning systems serves as "a platform or environment that offers interactive learning and teaching using interactive tools which can stand alone and can be networked" (Marlia Puteh \& Supyan Hussin, 2007, p. 1179). E-Learning is conducted either through the mode of online distance learning (a mixed mode-a reduced face-to-face teaching situation plus online) and/or open distance learning ('virtual learning') which offers all the courses in the e-Learning format (Bates, 2001).

Studying in an e-Learning mode is successful if users are computer literate and skillful at handling computers. However, to adult learners who undergo online distance education, and who are accustomed to the face-to-face approach, the idea of learning via ICT is too daunting (Bingimlas, 2009) despite the Internet boom in these decades. Some may feel resistant to computers and are scared of using them, thus developing technophobic students who prefer 
not to integrate ICT in language learning. Studies have shown that computer phobia among adult university students has become a prevalent phenomenon (see Hauser, Paul, \& Bradley, 2012; Xie, 2012; Rahimi \& Yadollahi, 2011). The researchers found that many adult learners had high computer anxiety and low self-efficacy due to lack of ICT knowledge and skills.

Learning via ICT requires self-directed or independent learning. To lower proficient English language learners, learning English via online is another obstacle that they have to endure. This is due to the fact that language is a skill subject which requires more language drilling and practices rather than a content subject (Rahimi \& Yadollahi, 2011; Chan \& Han, 2005; Razak \& Embi, 2004). University students are required to possess a large volume of academic and specialised vocabulary for successful communication in a university (see Laufer, 2013; Kamariah Yunus, Mahani Mohamad, \& Borden Waelateh, 2016). To the beginner of English, they need constant supervision from the course instructors to guide them to learn English vocabulary and the four English skills (listening, speaking, reading, and writing) before self-directed learning can take place (Kamariah Yunus, 2015; Lu, Woodcock, \& Jiang, 2014). By not providing sufficient foundation and support both in ICT and language skills, they will become computer-phobic in return.

\section{Literature Review}

Technology is taking over all aspects of life. Education, work, leisure, and law, among others, are all becoming increasingly dependent on being able to interact with technology (Hauser et al., 2012). Lack of ability to cope with this technology may produce a psychological effect termed as technophobia.

Technophobia is defined as the action or behaviour of dislikes the technologies. It can be also defined as the negative attitude towards computers or information technology (Brosnan \& Lee, 1998). Rosen and Weil (1990) have defined technophobia as evidence of one or more of the following: (a) anxiety about present or future interactions with computers or computer-related technology; (b) negative global attitudes about computers, their operation or their societal impact; and/or (c) specific negative cognitions or self-critical internal dialogues during present computer interactions or when contemplating future computer interactions.

Despite technological advancement in this digital age, technophobia is still a persistent issue. It depends on many factors such as age, gender, experience, attitudes, background, ethnicity, computer availability and school socioeconomics. Experience with computers will reflect the attitudes towards computer. If students have less computer experience, it will reflect negative attitudes towards computer and therefore, it will give high impact to the level of technophobia. Computer attitudes have been shown to correlate positively with computer experience (Akarsu1 \& Akbıyı, 2012; Li \& Kirkup, 2007).

In terms of gender, male and female have different approaches to computers. Through games, boys learn to regard computers as toys or as technology to be mastered (Colley \& Comber, 2003). Males can communicate with the computer in an exploratory manner while females use computer just as a tool to complete their work and task. Males have more interest in computers and had more confidence in working with computers than female did (Hauser et al., 2012).

Some studies suggest that technophobia, as measured using the scales developed by Rosen et al (1992), is not related to gender (Chen, 2012) or that the effect is small (Lin, Shih, \& Lu, 2013). However, the results are conflicting, with some indicating a generally small to moderate gender difference in computer anxiety (Raman, 2011) and others indicating no significant difference in computer anxiety or attitudes (Brosnan \& Lee, 1998). They, however, noted that there were no gender differences for computer anxiety in the United Kingdom but a higher level of anxiety amongst males in Hong Kong suggested that cultural influences may be relevant. Chen (2012) found that females are generally more anxious than males among a university undergraduate population. However, the strength of this relationship is not conclusive. Laizu (2014) suggest that the reason for a reduced gender gap in technophobia over the last number of years is women's increased exposure to computers at third level. In light of evidence mentioned from previous research and given the importance of adult learners to integrate ICT in their education, this study aims to examine the level of anxiety of the adult learners, and to compare the level of computer phobia between the male and female students.

\section{Method}

This research was designed as a descriptive study. The sample was purposively chosen from the second batch of adult students (aged 27-50) who underwent UBI 3012 English for Communication subject offered by the Faculty of Languages and Communication, UniSZA. They were the Arabic and Islamic Religious teachers who attended the first degree programme sponsored by the Ministry of Education of Malaysia. Passing this English course is compulsory since this is a requirement subject, and they attended this course in the second semester of the four-year programme. The respondents were the students of the Faculty of Islamic Contemporary, Universiti Sultan Zainal Abidin (UniSZA), Malaysia. Their proficiency level ranges from very low to average. Even though a total of 200 students registered the course, only 106 (25 male and 81 female students) agreed to participate in the study. The students were taught by the three researchers, and each researcher taught two groups.

The data used was a set of questionnaire comprising three sections and 65 items. The respondents were required to give their opinions to each statement ranging from Likert scale 1 (Strongly Disagree) to 7 (Strongly Agree). The present study adopted Rosen and Well's (1992) Measuring Technophobia Instruments (MT) due to its widespread acceptance. 
The reliability of the items in the scales (CARS-C, 0.83; IAS, 0.75; CSE, 0.78) exhibited a high degree of reliability. Table 1 showed the Cronbach's Alpha coefficient levels of the three scales.

Table 1. Reliability coefficients for measurement instruments

\begin{tabular}{lc}
\hline Instrument & Cronbach's alpha coefficient \\
\hline CARS-C (Computer Anxiety Rating Scale) & 0.890 \\
\hline IAS (Internet Attitude Scale) & 0.801 \\
\hline CSE (Computer Self-Efficacy Scale) & 0.963 \\
\hline
\end{tabular}

The instruments consisted of:

(1) 17 Likert-scale items of the computer anxiety rating scale (CARS-C). According to Rosen and Weil (1992), the issues addressed in this questionnaire are: (1) anxiety related to the machines themselves; (2) their role in society; (3) computer programming; (4) computer use; and (5) problems with computers and technology. The respondents were required to indicate how anxious or nervous each situation would make them feel by indicating their agreement with the statements related to computer anxiety scaled from 1 (LOW) to 10 (HIGH).

(2) 20 Likert-scale items of the Internet Attitudes Scale (IAS). This scale comprises three categories: Negative Computer Cognitions (11 items), Positive Computer Learning Cognitions (5 items) and Computer Enjoyment (4 items). The items assess the students' attitudes towards the Internet. The norms established by Rosen and Weil for computer phobia in this category are as follows: no computer phobia, 69-100; low computer phobia, 61-68; moderate to high computer phobia, 20-60. These ranges are in contrast to the CARS, wherein high scores are indicative of computer phobia. The respondents were required to indicate their agreement with the statements related to the students' attitudes towards the Internet scaled from 1 (LOW) to $10(\mathrm{HIGH})$.

(3) 28 Likert-scale items of Computer Self-Efficacy Scale (CSE). Computer self-efficacy commonly refers to individuals' judgment of their knowledge and capabilities to use computers in diverse situations. These items aim to assess the students' computer self-efficacy by indicating their agreement with the statements related to the students' computer self-efficacy scaled from 1 (LOW) to 10 (HIGH). The CSE was not measured however in the present study.

Rosen and Weil (1992) divided the three measures (Computer Anxiety, Internet Attitudes Scales, and Computer SelfEfficacy) into three levels of technophobia - No Technophobia (20-41), Low Technophobia (40-49) and Moderate/High Technophobia (50-100). They also defined an overall measure of technophobia based on a combination of the measures (CTS). These questionnaires were chosen as data collection tool or instrument since they are less time-consuming, and at the same time, they were less expensive compared to the face-to-face interview. The data were collected during the fourth (last) teaching session of the semester.

The questionnaires were designed to be self-administering. The participants in the six groups (A, B, C, D, E, and F) were told to read carefully the instructions as they vary for each questionnaire. They were also assured that their responses would remain anonymous and confidential, and the questionnaires were $\mathrm{not}$ a imed to gain the right or wrong answers. No time limits were imposed on the questionnaires, but they were generally completed within one hour. In this research, data were analysed descriptively (in percentages) using the SPSS (Statistical Package of Social Sciences) version 17.0.

\section{Results and Discussion}

This study aims to examine the level of technophobia of adult university students in the Faculty of Islamic contemporary, UniSZA, Malaysia, and to identify whether technophobia is experienced differently across gender. Table 1 showed that half of the students $(50.2 \%)$ reported no computer phobia, as evidenced by the CARS. However, the statistics reveals that a substantial majority of the students $(89.9 \%)$ could be designated as low to highly computer phobic, as evidenced by the IAS.

Table 2. The levels of computer phobia

\begin{tabular}{lll}
\hline Level & CARS & IAS \\
None & $20-41(50.2 \%)$ & $69-100(10.1 \%)$ \\
Low & $42-49(21.9 \%)$ & $61-68(42.1 \%)$ \\
Moderate to high & $50-100(27.9 \%)$ & $20-60(47.8 \%)$
\end{tabular}


When comparing between the two groups (male and female students), data showed evidence of the presence of different levels of computer phobia (see Table 3). The level of computer phobia of female students was shown to be higher than that of the male students. The same result was also indicated under IAS scale. Female students (30\%) compared to male students $(20 \%)$ were shown to be moderate to highly technophobic.

Table 3. The levels of computer phobia of PPG students

\begin{tabular}{lllll}
\hline & $\begin{array}{c}\text { Computer } \\
\text { (CARS); n=151 }\end{array}$ & Anxiety & Scale & \multicolumn{2}{c}{$\begin{array}{l}\text { Internet Attitudes Scale (IAS) } \\
\mathbf{n}=\mathbf{1 5 1}\end{array}$} \\
$\begin{array}{l}\text { Students } \\
\text { Male (M) Female (F) }\end{array}$ & & $\mathrm{M}(\mathrm{n}=31)$ & $\mathrm{F}(\mathrm{n}=120)$ & $\mathrm{F}(\mathrm{n}=120)$ \\
No Technophobia & $20-41$ & $20-41$ & $69-100$ & \\
& $(48 \%)$ & $(42 \%)$ & $(25 \%)$ & $(19 \%)$ \\
Low Technophobia & $41-49$ & $41-49$ & $61-68$ & $61-68$ \\
& $(33 \%)$ & $(28 \%)$ & $(55 \%)$ & $(51 \%)$ \\
Moderate to High & $50-100$ & $50-100$ & $20-60$ & $20-60$ \\
Technophobia & $(19 \%)$ & $(30 \%)$ & $(20 \%)$ & $(30 \%)$ \\
\hline
\end{tabular}

The first finding revealed that even though the respondents experienced less fear in learning the English subject online, as evident from the CARS results, their IAS or confident level was low. The negative attitudes and a low level of confidence indicate that the respondents did not confide totally in the online instruction given on KeLiP. This can be explained in terms of their first experience learning via online mode and the trust given to the e-Learning tool (KeLiP) as a source of knowledge provider. Their perceptions and views from an interview would be sufficed to know about their preference for the mode of instruction. However, as claimed by Sivakumaran and Lux (2011), this group of students was adult learners who 'return to school' after so many years not using English. Their readiness to use KeLiP, therefore, must be very low.

The fact that female students were more technophobic than their male counterparts were supported by many researchers (Hauser, Paul, \& Bradley, 2012; Xie, 2012; Rahimi \& Yadollahi, 2011; Bingimlas, 2009). The findings obtained in this study can be explained in many ways. First, women's attitudes were found to be more negative than those of men, and they were claimed to have higher computer anxiety than men. In a similar vein, males were reported to be significantly less anxious about the Internet than were females. The findings supported the 'implicit theory' which frames the principle of gender inequality in this study (Clark, 1988). The theory contends that gender inequality in e-Learning was the effect of learner differences which are observable in gender, age, and learning style. While male students are socially perceived as more capable of handling computer tools and apparatus, female students, on the other hand, do not see them as capable of dealing with advanced ICT.

The second explanation is much related to the societal perceptions on the role of male and females. Technophobia is the fear or dislike of advanced technology or complex devices, especially computer. As technologies emerge and enhance, they have become increasingly advanced and complicated to understand. People are more likely to become anxious to use these technologies (Kennedy, Dalgarno, Gray, Judd, \& Waycott, 2007; Brown \& Czerniewicz, 2004). While younger students were reported to experience less fear with ICT tools, adult learners would be more likely to adopt traditional gender roles where men would be seen as more 'technically able'. Adult female students, on the other hand, would thus be more likely to display higher levels of technophobia than do male adult students.

\section{Conclusion}

Despite having an ability to perform e-Learning applications, female students still suffer from a high level of computer technophobia than do their male counterparts. They still experience the feeling of anxiety and phobia towards computers even though they get helps from their male peers and course instructors. This psychological effect is drawn partly from the sense of insecurity that is experienced by many females especially in using tools. This study has implications for the top management of UniSZA, and both lecturers and students alike. The authoritative bodies in UniSZA have to review the ELLT syllabus and curriculum to suit the needs of local and international students. They have to take into considerations of teacher readiness, anxiety factors, and also motivation. Teachers' ability and competence in coping with technology online has to be measured. In the same time, learners have to be motivated and equally encouraged to use ICT in English language learning.

\section{Acknowledgements}

The authors would like to express their gratitude to Universiti Sultan Zainal Abidin, Malaysia for funding this research project under University Research Grant Scheme (URGS). 


\section{References}

Akarsu1, B., \& Akbıyık, C. (2012). Relationships among Perceived Computer Literacy Skills, Computer Attitudes, and Computer Self-Efficacy Levels. Journal of European Education, 2(2), 1-9.

Bates, A. W. (2001). National strategies for e-learning in post-secondary education and training. Paris: International Institute for Educational Planning, UNESCO.

Bingimlas, (2009). Barriers to the successful integration of ICT in Teaching and Learning Environments: A Review of the Literature. Eurasia Journal of Mathematics, Science \& Technology Education, 5 (3), 235-245.

Brosnan, M., \& Lee, W. (1998). A cross-cultural comparison of gender differences in computer attitudes and anxiety: The UK and Hong Kong. Computers in Human Behavior, 14 (4), 559-577.

Brown, C., \& Czerniewicz, L. (2004). Access to computers: Factors hindering and encouraging use of computers for teaching and e-learning in five regional higher education institutions in South Africa. In Proceedings of World Conference on E-Learning in Corporate, Government, Healthcare, and Higher Education 2004, Norfolk, VA: AACE.

Brown, C. \& Czerniewicz, L. (2007). If we build it will they come? Investigating the relationship between students' access to and use of ICTs for learning. South African Journal of Higher Education, 21 (6), 732-747.

Chan S. H. \& Han, A. L. (2005). What goes on when tertiary students are engaged in an online academic writing course? GEMA Online Journal of Language Studies, 5 (2), 1-13.

Chen, K. T-C. (2012). Elementary EFL teachers' computer phobia and computer self-efficacy in Taiwan. The Turkish Online Journal of Educational Technology, 11(2), 100-107.

Clark, C. (1988). Asking the right questions about teacher preparation: Contributions of research on teaching thinking. Educational Researcher, 17, 5-12.

Colley, A., \& Comber, C. (2003). Age and gender differences in computer use and attitudes among secondary school students: What has changed?. Educational Research, 45(2), 155-165.

Hauser, R., Paul, R., \& Bradley, J. (2012). Computer self-efficacy, anxiety, and learning in online versus face to face medium. Journal of Information Technology Education, 11, 141-154.

Kamariah Yunus., Mahani Mohamad., \& Borden Waelateh. (2016). The breadth of receptive vocabulary knowledge among English major university students. Journal of Nusantara Studies, 1(1), 7-17.

Kamariah Yunus. (2015). Data-driven learning and teaching of colligations of prepositions: The case of law undergraduates in Malaysia. Unpublished $\mathrm{PhD}$ thesis, University of Malaya.

Kennedy, G., Dalgarno, B., Gray, K., Judd, T., \& Waycott, J., (2007). The net generations are not big users of Web 2.0 technologies: Preliminary findings. In ICT: Providing choices for learners and learning. Proceedings ASCILITE Singapore 2007 (pp. 517-525). Singapore: ASCILITE.

Kern, R. (2006). Perspectives on technology in learning and teaching languages. TESOL Quarterly, 40 (1), $183-210$.

Laizu, Z. (2014). Role of information and communication technology (ICT): Women's Empowerment in Rural Bangladesh. Unpublished PhD thesis. Murdoch University.

Laufer, B. (2013). Lexical thresholds for reading comprehension: What they are and how they can be used for teaching purposes, Tesol Quarterly, 47(4), 867-872.

Li, N., \& Kirkup, G. (2007). Gender and cultural differences in internet use: A study of China and the UK. Computers \& Education, 48 (2), 301-317.

Lin, S. Shih, Tse-Hua, \& Lu, R. (2013). ICT Proficiency and gender: A validation on training and development. International Journal of Technology and Design Education, 23(2), 179-190.

Maimunah Mohd Shaha, Roshidi Hassana, \& Roslani Embi. (2011). Computer anxiety: Data analysis. Procedia - Social and Behavioral Sciences, 67 (2012), 275 - 286.

Marlia Puteh., \& Supyan Hussin. (2007). A comparative study of e-learning practices at Malaysian private universities. In: First International Malaysian Educational Technology Convention, 2007, 2-5 November 2007, Sofitel Palm Resort, Senai, Johor Bahru, Malaysia.

Ness, D., \& Chia-Ling, L. (Ed.). (2015). International education: An encyclopedia of contemporary issues and systems. Abingdon: Routledge.

Raman, A. (2011). The usage of technology among education students in University Utara Malaysia: An application of extended Technology Acceptance Model, International Journal of Education and Development using Information and Communication Technology, 7 (3), 4-17.

Razak, N., Embi, M.A. (2004). A framework of IT competency for English language teachers. Internet Journal of eLanguage Learning and Teaching, 1(1), 1-14.

Sivakumaran, T., \& Lux, A.C. (2011). Overcoming computer anxiety: A three-step process for adult learners. In USChina Education Review B 1. USA: David Publishing. Retrieved 13 August, 2016 from http://files.eric.ed.gov/fulltext/ED524800.pdf 